\title{
TOWARD AN ECLECTIC THEORY \\ OF INTERNATIONAL PRODUCTION: \\ SOME EMPIRICAL TESTS
}

JOHN H. DUNNING*

University of Reading

\begin{abstract}
This paper first sets out the main features of the eclectic theory of international production and then seeks to evaluate its significance of ownership- and location-specific variables in explaining the industrial pattern and geographical distribution of the sales of U.S. affiliates in fourteen manufacturing industries in seven countries in 1970.
\end{abstract}

There is now a consensus of opinion that the propensity of an enterprise to engage in international production - that financed by foreign direct investmentrests on three main determinants: first, the extent to which it possesses (or can INTRODUCTION The Underlying acquire, on more favorable terms) assets ${ }^{1}$ which its competitors (or potential competitors) do not possess; second, whether it is in its interest to sell or lease these assets to other firms, or make use of-internalize-them itself; and third, how far it is profitable to exploit these assets in conjunction with the indigenous resources of foreign countries rather than those of the home country. The more the ownership-specific advantages possessed by an enterprise, the greater the inducement to internalize them; and the wider the attractions of a foreign rather than a home country production base, the greater the likelihood that an enterprise, given the incentive to do so, will engage in international production.

This eclectic approach to the theory of international production may be summarized as follows. ${ }^{2}$ A national firm supplying its own market has various avenues for growth: it can diversify horizontally or laterally into new product lines, or vertically into new activities, including the production of knowledge; it can acquire existing enterprises; or it can exploit foreign markets. When it makes good economic sense to choose the last route (which may also embrace one or more of the others), the enterprise becomes an international enterprise (defined as a firm which services foreign markets). However, for it to be able to produce alongside indigenous firms domiciled in these markets, it must possess additional ownership advantages sufficient to outweigh the costs of servicing an unfamiliar or distant environment [Hirsch 1976].

The function of an enterprise is to transform, by the process of production, valuable inputs into more valuable outputs. Inputs are of two kinds. The first are those which are available, on the same terms, to all firms, whatever their size or nationality, but which are specific in their origin to particular locations and have to be used in that location. These include not only Ricardian type endowments - natural resources, most kinds of labor, and proximity to markets, ${ }^{3}$ but also the legal and commercial environment in which the endowments are used-market structure, and government legislation and policies. In classical and neoclassical trade theories, differences in the possession of these endowments between countries fully explain the willingness and the ability of enterprises to become international; 4 but since all firms, whatever their nationality of ownership, were assumed to have full and free access to them (including technology), there were no advantages to be gained from foreign production.

*John H. Dunning is Professor of International Investment and Business Studies at the University of Reading. He has been working in the field of international investment and the multinational enterprise since the mid 1950 s and has published several books and numerous articles on the subject.

The author is much indebted to Professor Guy Landry of Brandon University, Winnipeg who was responsible for most of the computational work behind Tables 3-6 and who assisted in writing the first draft of pages 12-23. 
The second type of input is that which an enterprise may create for itself-certain types of technology and organizational skills - or can purchase from other institutions, but over which, in so doing, it acquires some proprietary right of use. Such ownership-specific inputs may take the form of a legally protected rightpatents, brand names, trade marks - or of a commercial monopoly-the acquisition of a particular raw material essential to the production of the product-or of exclusive control over particular market outlets; or they may arise from the size or technical characteristics of firms-economies of large-scale production and surplus entrepreneurial capacity. It should be observed that these ownership advantages are not exclusive either to international or multinational firms. Some are applicable to all firms producing in the same location; others are those which a branch plant of an existing enterprise may enjoy over a de novo enterprise of the same nationality. ${ }^{5}$ But, because they operate in different locationspecific environments, multinational firms may also derive additional ownership advantages - such as, their ability to engage in international transfer pricing, to shift liquid assets between currency areas to take advantage of (or protect against) exchange fluctuations, to reduce risks by diversifying their investment portfolios [Rugman 1979], to reduce the impact of strikes or industrial unrest in one country by operating parallel production capacity in another and by engaging international product or process specialization [Dunning 1977].

The essential feature about these second types of inputs is that, although their origin may be linked to location-specific endowments, their use is not so confined. The ability of enterprises to acquire ownership endowments is clearly not unrelated to the endowments specific to the countries in which they operateand particularly their country of origin. Otherwise, there would be no reason why the structure of foreign production of firms of different nationalities should be different. But, in fact, it is so-and substantially so. A recently published paper [Dunning 1979] has shown that Japanese firms have a comparative advantage in the foreign production of textiles and clothing and consumer electronics; UK firms in food and tobacco products; Swedish firms in mechanical and electrical engineering; West German firms in chemicals; and U.S. firms in transport equipment. Such differences as these can be explained only by an examination of the characteristics of the endowments of the countries in which the multinational enterprises operate, and especially those of the home country, which normally give rise to the ownership advantages in the first place. Raymond Vernon's product cycle theory was among the first to use this approach from the viewpoint of U.S. direct investment abroad [1966]. More recently Birgitta Swedenborg [1979] has extended and applied it to a study of Swedish, U.S., and UK direct foreign investment. The paper by Dunning [1979] deals with the industrial structure of foreign direct investment of five countries: UK, Sweden, Japan, West Germany, and the U.S. asserting that the relationship between ownership- and locationspecific endowments is more complex than was once thought. Moreover, often a longish time lag may be involved; many of today's ownership advantages of firms are a reflection of yesterday's location advantages of countries.

But, whatever the significance of the country of origin of such inputs, they are worth separating from those which are location-specific, because the enterprise possessing them can exploit them wherever it wishes, usually at a minimal transfer cost. Moreover, unless it chooses to sell them, or the right to their use, to other enterprises, the endowments are-for some period of time at least-its exclusive property.

Both modern trade and international production theory have embraced this kind of endowment which is often mobile between countries but not between firms. Indeed, over the last twenty years there has been a convergence in the explanation of the movement of goods and of factor inputs across national boundaries. Alongside the neotechnology theories of trade, which assert that the extent 
to which a country possesses technology is a key determinant of patterns of trade in manufactured goods between nations [Hufbauer 1970; Hirsch 1974], there is the knowledge theory of direct investment, which explains the pattern of international production in terms of the distribution of knowledge between firms of different nationalities [Johnson 1970]. Parallel with the hypothesis that patterns of trade can best be explained by the extent to which enterprises in different countries possess monopolistic, scale, or product differentiation advantages, are the theories of direct investment which focus on product differentiation, entrepreneurial capacity and multiplant economies [Caves 1971, 1974].

In the last five or six years, it has become increasingly recognized that neither a location nor an ownership endowment approach, by itself, can satisfactorily explain all forms of trade-although particular kinds of trade may be better explained by one approach rather than by another [Hirsch 1976]. It is now also accepted that an ownership endowment approach (first pioneered by Kindleberger and Hymer and later refined by Caves) is a necessary but not a sufficient condition for explaining international production. Only if both of the right dispositions of resource endowments exist between countries and firms of different nationalities will international production take place.

There is one final strand to the eclectic theory of international production. The possession of ownership advantages determines which firms will supply a particular foreign market, whereas the pattern of location endowments explains whether the firm will supply that market by exports (trade) or by local production (non-trade). But why does a firm choose to use the ownership advantages itself to exploit a foreign market-whatever route it chooses-rather than sell or lease these advantages to a firm located in that market to exploit? Why does it internalize its capital, technology, management skills itself to produce goods rather than externalize their use by engaging in portfolio investment, licensing, management contracts, and so on?

The basic incentive of a firm to internalize its ownership endowments is to avoid the disadvantages, or capitalize on the imperfections, of one or the other of the two main external mechanisms of resource allocation-the market or price system and the public authority fiat. Market imperfections arise wherever negotiation or transaction costs are high, wherever the economies of interdependent activities cannot be fully captured, and wherever information about the product or service being marketed is not readily available or is costly to acquire. From a buyer's viewpoint, such imperfections include uncertainty over the availability and price of essential supplies and inability to control their timing and delivery. From a seller's viewpoint, the preference for internalizing will be most pronounced where the market does not permit price discrimination, where the costs of enforcing property rights and controlling information flows are high, or where, in the case of forward integration, the seller wishes to protect his reputation by ensuring a control over product or service quality or after-sales maintenance [Brown 1976]. For both groups of firms, and for those considering horizontal internalization, the possession of underutilized resources - particularly entrepreneurial and organizational capacity, which may be exploited at low marginal cost to produce products complementary to those currently being supplied-also fosters internalization.

Public intervention in the allocation of resources may also encourage firms to internalize their activities. This arises particularly with respect to government legislation toward the production and licensing of technology, including the patent system, and where there are differential tax and exchange rate policies, which multinational enterprises may wish either to avoid or exploit.

As described then, the propensity to internalize ownership or location advantages ${ }^{6}$ make up the third strand in the eclectic theory. In most of the conventional literature on trade and international investment, it is this last aspect of the theory 
that has been most seriously neglected. For it is not just the possession of technology per se which gives an enterprise selling goods embodying that technology an edge over its international competitors, but also the advantages which arise from internalizing that technology rather than selling it to a foreign producer for the production of those goods. In other words, without the advantages of internalization much of direct foreign investment would be replaced by the international transaction of resources on a contractual basis between independent buyers and sellers.

To conclude this brief theoretical introduction, a matrix is presented which attempts to relate, in an encapsulated form, the main types of activities in which multinational enterprises may be involved to the three main determinants of international involvement. (See Table 1). Such a table may be used as a starting point for an examination of the industrial and geographical distribution of foreign direct investment. It will be noted that as part of the explanation of ownership endowments, the possession of home country endowments has been added because these will influence the geographical origin of such investment.

AN OVERVIEW OF CURRENT APPROACHES
Broadly speaking, there have been five approaches to testing the theory of international production. The first has attempted to explain the causes of direct foreign investment by examining its industrial composition from the viewpoint of individual home countries (almost exclusively the U.S.) and host countries (notably Canada, UK, and Australia). A common thread running through all these studies $^{7}$ is that they have sought to explain the pattern of foreign direct investment in terms of ownership advantages of MNEs. The second approach has been to look at the form of international economic involvement and to identify the determinants of whether foreign markets are exploited by trade or nontrade routes. ${ }^{8}$ The third has combined the two approaches by examining both the level and composition of international involvement in terms of ownership and locational characteristics. ${ }^{9}$ The fourth approach has been to extend the first three to incorporate the internalization thesis; 10 and the fifth has been to relate the specific endowments of firms to those of home countries, as in Vernon [1966]; Swedenborg [1979]; and Dunning [1979]. The empirical contribution of this paper is primarily of the third kind but with the issues of the fourth very much in mind.

From both a technical and motivational standpoint, these strands of research have much in common. ${ }^{11}$ Each uses, with varying degrees of sophistication, multiple regression analysis to test explanations about the relationship between various measures of international involvement and a variety of explanatory variables. Each, too, is beset by the same kind of methodological and statistical problems, notably the establishment of operationally testable hypotheses, data limitations, and multicollinearity between the individual variables. From a motivational standpoint, with one exception [Knickerbocker 1973], all the studies assume either that enterprises are profit maximizers or that their behavior is not inconsistent with that which might be expected from a profit-maximizing firm.

In testing empirically two of the most important hypotheses implicit in the eclectic theory of international production, only two forms of international economic involvement-exports and production-are considered; these are assumed to be alternative to each other in servicing foreign markets. ${ }^{12}$

The data used cover the foreign activities of U.S. multinationals in fourteen manufacturing industries in seven countries in 1970, as published by the U.S. Tariff Commission [1973], details of which are set out in Appendix $2 .{ }^{13}$ The two basic hypotheses are:

$\mathrm{H} 1$ The competitive advantage of a country's enterprises in servicing foreign markets is determined both by the ownership advantages of these enterprises relative to those of enterprises of other nationalities, and the location 


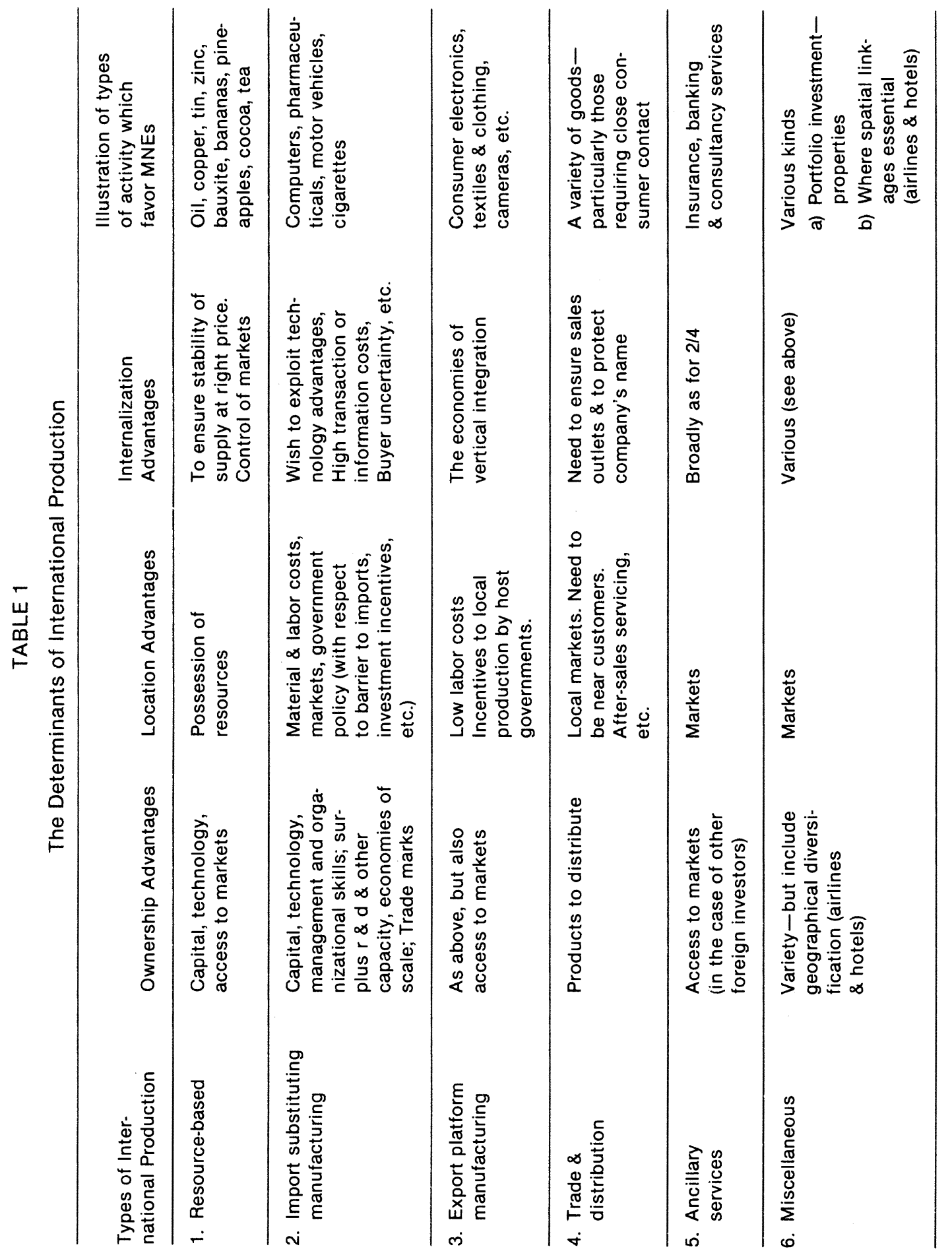


advantages of the countries in which they produce relative to those of other countries.

H2 The form of the involvement, or participation, will essentially depend on the relative attractiveness of the location-specific endowments of the home and host countries. ${ }^{14}$

That the gains to be derived from internalizing activities, which would otherwise be allocated by markets or government fiat, make up an important part of ownership advantages, and, in some cases, of location advantages as well is also contended.

Concerning $\mathrm{H} 1$, we shall take as our dependent variable the share of the output of a particular industry (IS) in a particular country supplied by exports (X) plus local production (AS) of U.S.-owned firms: ${ }^{15}$ AS + X/IS. These components can, of course, be considered separately; but, in this hypothesis, we wish to exclude location-specific variables influencing the form of involvement. This dependent variable is notated as DV $1 .{ }^{16}$

The two components of international involvement may be considered separately. DV 2 signifies the share of the affiliates' sales of total output in the host country (AS/IS), and DV 3, the share of exports from the U.S. of that output (X/IS).

Concerning $\mathrm{H} 2$, the dependent variable-DV 4 -is defined as $X / 1 S \div A S / I S$ (or simply X/AS); in other words, it is the ratio between exploiting a particular market by exports from the U.S. relative to local production by U.S. affiliates in the country of marketing. The higher this ratio, the more the U.S. is favored as a location for production, relative to the country in which the goods are being sold (or being exported from).

THE STATISTICAL TESTING

The Dependent Variables:
We now turn to a statistical testing of the two main hypotheses.

\section{Hypothesis 1-The international competitive hypothesis}

The overall involvement index reflects both location-and ownership-specific advantages. The explanation of the foreign production ratio lies in identifying and measuring ownership advantages (as the location of production is assumed to be the same for all firms) and that of the export ratio in both location and ownership advantages. Looking at the export ratio, one naturally turns to trade theories for guidance; but no attempt, to our knowledge, has been made to explain shares of a particular industry's sales accounted for by foreign imports. ${ }^{17}$ In discussing the determinants of foreign production, one should be concerned solely with ownership advantages; yet, the fact that trade and production are often related to each other suggests that these advantages may also be associated with locationspecific endowments. ${ }^{18}$ Explanations of foreign production, which ignore the latter advantages, are likely to be inadequate, thus supporting the need for an eclectic theory of production and trade.

The share of a particular industry's output supplied by foreign affiliates is determined by the competitive advantages of the affiliates and the relative attractions of the host country as a production base. It is likely to be greatest where the barriers to entry facing indigenous producers and exports from the home (and other countries) are highest. Trade is similarly determined except that it will flourish where barriers to exports are low and where barriers to entry to all producers in the host country are high. International involvement is determined simply by the competitive advantage of the investing and exporting firms vis-a-vis indigenous and other foreign companies.

In symbolic terms:

$$
\text { DV } 1 \quad A S+X / I S=f(C)
$$




$$
\begin{array}{ll}
\text { DV } 2 & \text { AS/IS }=f(C, X / A S) \\
& \text { and } \\
\text { DV } 3 & X / I S=f(C, X / A S)
\end{array}
$$

\section{Hypothesis 2-The location hypothesis}

This is simple and straightforward. To produce a particular good, an enterprise will choose that location which best advances its overall goals. The interface between received location theory and the MNE is a relatively unexplored territory, but a good start has been made by Vernon [1974]. In principle, there is no reason to suppose a national multiplant firm would behave very differently if its plants were located in a different country. New variables - such as exchange risks, differences in taxation rates, and policies of host governments toward inward direct investment-may need to be incorporated, but this can be done without too much difficulty.

The location hypothesis is solely concerned with country-specific variables affecting (1) the size and character of markets (which may be affected by competitor's behavior) and (2) production and transfer costs, though these may have a special impact on MNEs because of their ability to internalize the costs and benefits of some of the differences which exist between countries. The hypothesis may be expressed as:

$$
\begin{gathered}
\text { DV } 4 \text { X/AS }=f(L) \\
\text { where } L=\text { locational advantage of the home country } \\
\text { (to be defined). }
\end{gathered}
$$

\section{Hypothesis 1}

To assess the competitive advantage of firms of one nationality over those of another-both in particular industries and countries-one must evaluate: (1) allocative, technical, and scale efficiency; (2) product range and quality; and (3) market power. Because we are concerned with inter-industry comparisons, allocative efficiency of resources between industries may be discounted. However, goals may differ between firms, as may the competence of firms to achieve these goals. For example, the greater the innovative ability of an enterprise, the more resourceful and the more talented its managerial and labor force, the higher its market share is likely to be. Similarly, the advantages of size, of being part of a larger organization, and of being able to internalize external economies will affect a firm's competitive situation independently of the location of its activities.

Some of these variables, of course, reflect the industry or country characteristics of firms. Governments, for example, can and do influence the extent to which there is an adequate labor force to draw upon, the promotion of new technologies, the role of advertising in fostering product differentiation, and so on. These factors are acknowledged and have been considered explicitly elsewhere [Dunning 1979].

It may be helpful to break $\mathrm{H} 1$ down into two sub-hypotheses.

The first is:

$\mathrm{H} 1_{\mathrm{a}}$ Given the export-participation ratio (X/IS), the foreign production-participation ratio (AS/IS) will be highest in those industries where the comparative advantage of foreign (meaning U.S. here) firms is greatest vis-a-vis indigenous firms.

In principle, many of these advantages may be captured in a catchall measure, as in the comparative productivity of U.S. firms and host country firms or some proxy for integration-such as, percent of net to gross output. The comparative advan- 
tage of U.S. firms is presumably highest where their relative productivity or valueadded ratio is highest; therefore, in those cases, the affiliate penetration ratio should be highest. In practice, difficulties in measuring productivity and identifying internalizing economies make both measures of doubtful applicability.

$\mathrm{H} 1_{b}$ Given the production-participation ratio (AS/IS), the export penetration-participation ratio (X/IS) will be highest in those industries where the national resource endowments of the U.S. are greatest in comparison to those of other countries, and where barriers to trade are minimal.

Location theory approaches export success more in terms of difference in absolute production costs and the costs of traversing space. Artificial barriers to trade include those imposed by governments or imperfect markets. An incentive to export may also result from the inability of a host country's firms to compete effectively, due to the absence of a market sufficiently large to yield economies of scale in production.

\section{Hypothesis 2}

Like $\mathrm{H}_{1}$, the second hypothesis appears to be explained best by the theories of trade and location. Among the relative costs that play an important part in determining the location choice are those of labor and material inputs. The former are particularly critical in this study because it is limited to manufacturing industries where horizontal direct investment is the rule. This is in contrast to the situation in resource industries where vertical direct investment plays a much greater role. By the same token, labor productivity and its growth will be important elements in determining the real value of labor.

Production costs may be closely related also to the scale of plant which can be built. Market size will, therefore, be relevant. So, also, will rates of growth of the markets involved because they will determine the extent to which economies of scale may be exploited in the future.

The Choice of Independent Variables for this Exercise
Table 2 lists some of the variables which might be considered as proxies for ownership-and location-specific advantages. An asterisk identifies those variables which might also be used as indices of internalization advantages. ${ }^{19}$ Some of these are very similar to each other; not all can be used for this particular exercise, partly because it is concerned with explaining patterns of involvement by industries rather than by firms, and partly because of data constraints.

It will also be noted that for some variables set out, data are required for host countries; in others, for the home country, or for both host and home countries. Where only the home country is involved, location advantages become irrelevant, and one cannot use the data to determine both industry and country participation ratios. The main constraint, however, has been the paucity of good data about host countries which seriously inhibits testing both hypotheses for the seven countries considered separately. This exercise omits the two LDCs, partly because the data are less certain for these two countries, and partly so that a tariff variable could be used-data for which were not available for Mexico and Brazil. In the end, the independent variables were chosen and used to test both hypotheses. Data on each relate to 1970 , or the nearest year, except where otherwise stated. The data for these variables were extracted mainly from the U.S. Tariff Commission Study, except for those on imports which were obtained from the OECD Commodity Trade Statistics Series C, and tariffs from a Political and Economic Planning publication [1965]. 
TABLE 2

Ownership and Location Advantages

(Internalizing Advantages Marked with *)

By Industry and/or Country

Ownership Advantages: Specific Determinants

1. Access to Productive Knowledge

(a) Skilled (professional and technical)! unskilled labor ratio*

Home cf. host firms

(b) R and D as percent of sales*

Home cf. host firms

2. Economics of the Firm

(a) Size of enterprise*

Home firms

(b) Relative size of enterprises

(c) Number of nonproduction to all workers * or wage bill of nonproduction to all workers or nonproduction costs $1 /$ total costs * (gross output) or R and D plus advertising costs to total costs (or sales)*

(Average) Home cf. host firms

(d) Capital/Labor ratio

3. Opportunities for Investment
(a) Size of local market
(b) Size of/or local market plus exports

4. Diversification Indices ${ }^{2}$
(a) Average number of countries MNEs operate in * or
(b) $\%$ of foreign/total production of home firms *
(c) \% of intragroup exports to total exports of MNEs *

(d) Number of product groups in which parent companies produce or $\%$ of output of main product group to all output *

Home firms

(e) \% of shipments from multiplant enterprises to total shipments (in home country)*

Home firms

5. Market Concentration
(a) Percentage of output of industry accounted for by " $x$ " largest firms

Home firms

6. Efficiency

(a) Wage costs (per man hour) of production workers

Foreign affiliates as \% of home firms

7. Resource Availability

(a) \% of main material(s) imported *

(b) \% of main material(s) used in production process

Either import/export ratio of home firms or \% imports to total consumption

$\%$ of main material costs to gross output

8. Product differentiation Advertising/sales ratio

Home firms

9. Oligopolistic Behavior Entry Concentration Index Knickerbocker Ph.D. thesis

Home firms in host countries

${ }^{1}$ Nonproduction $=$ pre -+ post - direct production costs.

${ }^{2}(a)-(d)$ specific to MNEs; (e) general to multi-plant enterprises. 
TABLE 2 (continued)

Ownership Advantages: Specific Determinants (Internalizing Advantages Marked with *)

Determinants
By Industry and/or Country

\section{Ownership Advantages: General Determinants}

1. Productivity

Net output or sales per man

2. Profitability

Profits/assets or sales

3. Growth

Increase in sales

1. Home firms cf. host firms

2. Foreign affiliates $\mathrm{cf}$. host firms

1. Home firms cf. host firms

2. Foreign affiliates $c f$. host firms

1. Home firms cf. host firms

2. Foreign affiliates $\mathrm{cf}$. host firms

\section{Location Advantages: Specific Determinants}

1. Production Costs

(a) Wages per man hour

(b) Energy costs (e.g. electricity or oil)

(c) Materials costs (cost of major inputs; or commodity price indicies for main materials) or some index of resource availability

(d) Tax rates (including, where possible, tax allowances) *

(e) Average number of countries MNEs operating in

2. Transfer Costs
(a) Transport costs
(b) Tariffs
(c) Non-tariff barriers

3. General

(a) Political risks
Home firms cf. host firms

Home firms cf. host firms

Home firms cf. host firms

Home firms cf. host firms

Home firms only

Home-host country

Host country

Host country

Host country

Location Advantages: General Determinants

1. Productivity
(a) Production costs per man or
Home firms cf. foreign affiliates
(b) Net output or sales per man
Home firms cf. foreign affiliates
Profits/assets or sales
Home firms cf. foreign affiliates

(A) For the Seven
Country Exercise

\section{(i) Ownership-specific variables}

1a SER-Skilled employment ratio: the ratio of salaried employees to production employees for all firms in the host countries.

2a AHC-Average hourly compensation of all employees in the host countries. (1a and $2 \mathrm{a}$ are both measures of human capital intensity). 
3a RSM-Relative sales per man (an efficiency index: the sales per man year of firms in the U.S. divided by sales per man year of firms (including the affiliates of U.S. firms) in the host countries.

4a GRSPM-Growth in sales per man of all firms (in the host country), 1966-1970.

The predicted sign for each of these variables for each of the hypotheses is positive, but their significance is likely to be greater for $\mathrm{H} 1$ than $\mathrm{H} 2$. U.S. firms will invest in those industries and countries in which they have the greatest technological advantage and where their productivity, vis-a-vis local firms, is the highest.

\section{(ii) Location-specific variables}

5a XMR-The export/import ratio, measured by the ratio of value of exports to value of imports of host countries (as a measure of a country's ability to produce particular products).

6a RMS-Relative market size: value of industry sales in the U.S. divided by value of industry sales in the host countries.

7a RW-Relative wages: average hourly compensation (in particular industries) in the U.S. divided by average hourly compensation in the host countries for all employees (an often quoted cost determinant of foreign production).

8a RES-Relative export shares of U.S. and host countries: another measure of country performance.

9a CMG-Comparative market growth of U.S. (domestic industry local sales plus imports) and host countries, 1966-1970.

The predicted signs of these variables vary. In the case of RES it is positive; but in the case of XMR, RMS, and CMG it is negative. It might also be expected that these variables would be most demonstrated as an explanation of $\mathrm{H} 2$.

\section{(iii) General performance indicators}

10a AVIS-The average ratio of net income to sales of all firms in different industries and countries for 1966 and 1970.

11a MG-Market growth (domestic industry local sales plus imports) in host countries, 1966-1970.

The predicted sign of AVIS is negative for $\mathrm{H} 1$ but positive for $\mathrm{H} 2$; that for MG is positive for all hypotheses.

As per 1a-11a, but with an additional location-specific variable.

12b TR-Average tariffs measured on a country and industry basis.

The predicted sign of this variable is negative for DV4.

Such a large number of independent variables invites problems associated with multicollinearity. These problems were compounded when the two different groups of independent variables were tested against the 'wrong' dependent variables as well, in order to determine if the general hypotheses were too restrictive. It was, therefore, decided to correlate separately each of the independent variables with the dependent variables (DV1-4) to determine which ones appeared worthy of further statistical investigation. Only those which approached significance at a 95 percent level were incorporated into multivariate form.

The large number of equations tested, given four dependent variables and twelve independent variables, also sharply increased the possibility of chance significance. Because of this, any value below the 99 percent significance should be treated with caution.

(B) The Five Advanced Countries 
STATISTICAL RESULTS

Case A: The Seven Countries

These countries vary quite considerably in income levels, economic structure, political ideologies, culture, proximity to the U.S., and the extent to which they, themselves, spawn MNEs which compete in international markets with U.S.-based MNEs. It would not be surprising to find that different factors explain the absolute and relative success of U.S. exports and affiliate production in these countries when tested individually; here, however, we are concerned with factors which explain export and affiliate success in the seven countries as a group, and which can, perhaps, be regarded as "worldwide" determinants of such success. H1 (DV1-3)

Table 3 summarizes the more significant results of our regression analyses. ${ }^{20}$ The explanatory variables presented were extracted from the bivariate analysis and a series of multivariate equations constructed from them. For each of the variants of $\mathrm{H} 1$, most of the variation in the share of U.S. firms in the output of countries can be put down to two or three variables, with the best results coming from the overall international competitiveness index (DV1).

Because there are 98 observations, the explanatory power of the three variants of the hypothesis is encouraging. All of the signs (apart from that of RW) are consistent and in the right direction.

The equations reveal that the main advantages of U.S. firms are revealed in one location-specific variable-relative market size (RMS)-and one ownershipspecific variable - the skilled employment ratio (SER). This latter ratio may be used as a proxy for internalizing advantages. Both are consistently significant at the two star-i.e., 99 percent-level for each of the dependent variables. The other ownership variables which are significant at this level for DV1 and DV3 are the productivity index, relative sales per man (RSM), and average hourly compensation (AHC). Two location-specific variables-wage differentials (RW) and net income per sales (AVNIS) - are also significant for the same two dependent variables, but only at the 95 percent level. For DV2, no variables other than RMS and SER were significant, although average hourly compensation (AHC) came closest. That this last variable appears to be collinear with SER is not unexpected because higher salaries are usually obtained by more highly skilled nonproduction employees. These same relationships were run using the 1966 data; the results obtained were much the same with the exception that the 1966 profit variable, net income to sales (AVNIS), is never quite significant.

H2 (DV4)

The results obtained from this hypothesis set out in Table 4 are quite different from those of $\mathrm{H1}$. Two variables, the export/import ratio (XMR) and net income to sales (AVNIS), are consistently significant at the 99 percent level and explain nearly 60 percent of the variation in the location ratio. Growth of relative sales per man (GRSPM) comes very close but is never quite significant. The results for 1966 were virtually the same as for 1970 .

Case B: The Five Advanced Countries
Quite early in the study, it was decided to run the data with Mexico and Brazil excluded. Although, to a certain extent, each country exercises its own unique set of influences on the involvement of foreign firms, there is something to be said for separating Mexico and Brazil from the other five countries. Historically, LDCs have produced relatively more raw materials and semi-finished manufactures and fewer finished products for world markets than the developed countries, and investment in resource-based industries is often based on very different considerations than investment in manufacturing. ${ }^{1}$ Mexico and Brazil, in spite of recent rates of rapid industrial growth, are still sufficiently different in their stages of development to justify separate treatment. 


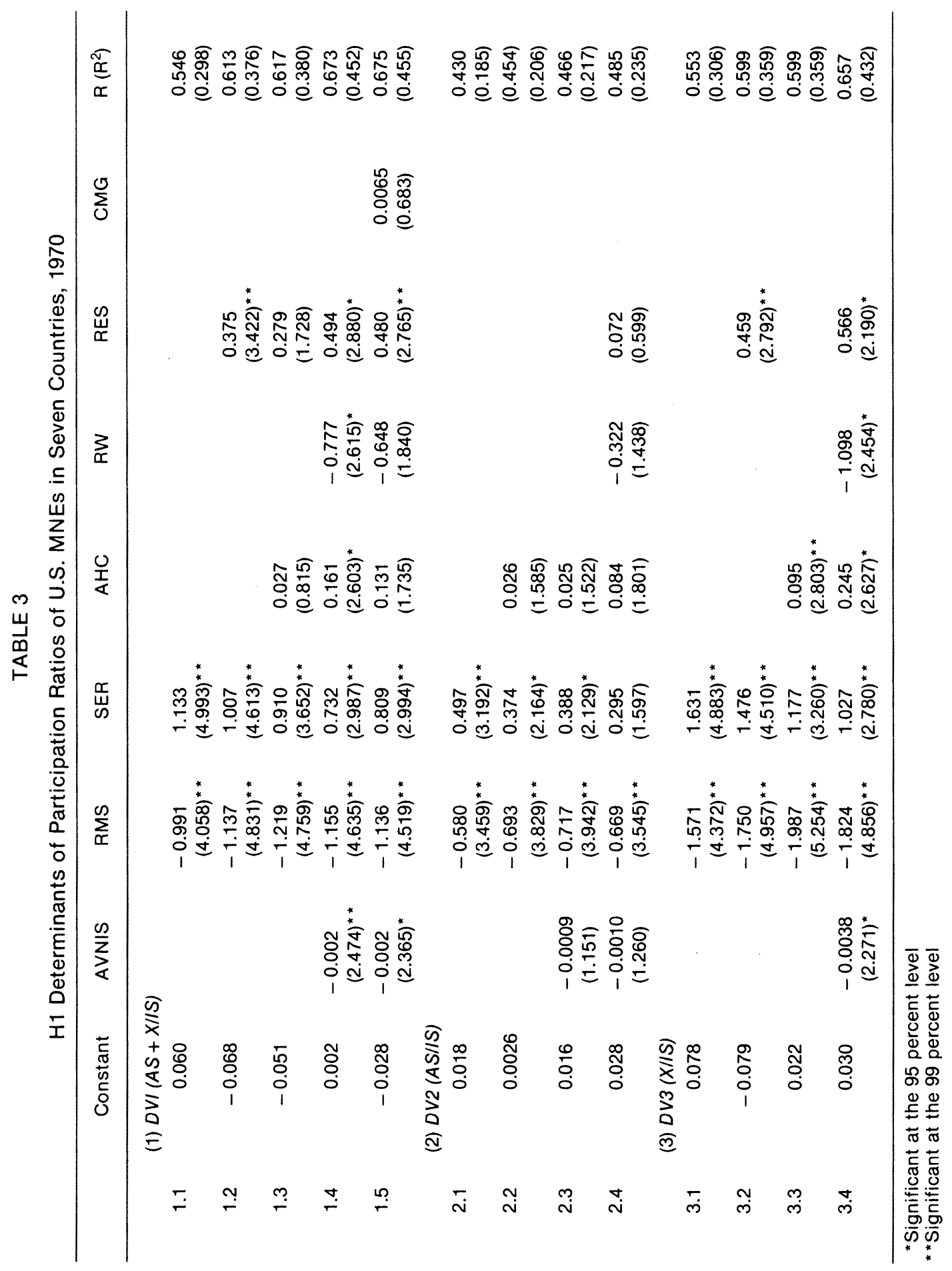


TABLE 4

H2 Determinants of Export/Local Production Ratios (X/AS) of U.S. MNEs (DV4) in Seven Countries 1970

\begin{tabular}{cccccccc}
\hline & Constant & XMR & AVNIS & RMS & RSM & CRSPM & R $\left(R^{2}\right)$ \\
\hline 4.1 & 0.308 & -0.101 & 0.043 & & & & 0.601 \\
& & $(3.301)^{* *}$ & $(7.256)^{\star *}$ & & & & $(0.362)$ \\
4.2 & 0.042 & -0.101 & 0.043 & & & 0.0085 & 0.622 \\
& & $(3.363)^{* *}$ & $(7.277)^{\star *}$ & & & $(1.942)$ & $(0.386)$ \\
4.3 & 0.103 & -0.099 & 0.042 & -0.561 & & 0.0084 & 0.624 \\
& & $(3.210)^{\star *}$ & $(7.007)^{\star *}$ & $(0.600)$ & & $(1.896)$ & $(0.389)$ \\
4.4 & 0.100 & -0.100 & 0.042 & & -0.0000048 & 0.0090 & 0.623 \\
& & $(3.287)^{\star *}$ & $(7.101)^{\star *}$ & & $(0.441)$ & $(1.983)$ & $(0.388)$ \\
\hline
\end{tabular}

H1 (DV1-DV3)

The results are presented in Table 5. In all equations, one ownership variable, the skilled employment ratio (SER), and two location variables, relative market shares (RMS) and average hourly compensation (AHC), are consistently significant at the 99 percent level. These three variables clearly have some influence on both U.S. trade and affiliate success in each of the five countries. Relative export shares (RES) and relative wages (RW) appear significant at the 95 percent (and in one case at the 99 percent) level in some of the equations of DV2 and DV3, but only where there are few independent variables regressed together. This suggests that these latter two location variables exert some influence on the competitiveness of U.S. trade but not on that of foreign production.

The tariff variable $(T)$ appears to be a significant explanation of the overall involvement of U.S. firms in the five countries. In combination with the three universally successful variables above (RMS, SER, and AHC), T yielded an $R^{2}$ of 0.5695 , which is quite satisfactory.

The data for 1966 suggest much the same results, with the exception that, in some combinations involving four or fewer independent variables, RS and RW also become significant as an explanation of DV1. This fact rather weakens the argument, based on the 1970 data, that these two have an influence on trade but not on foreign production; but probably they are only marginally significant in all three cases. For both years, 1966 and 1970, when the number of independent variables is increased, these two variables become less significant; this suggests that the added variables capture the significant influences duplicated in RES and RW. There appears, for example, to be a fair amount of collinearity between RW and AHC and between RES and RSM. For 1970, the correlation coefficients (at the seven-country level) between these variables are 0.9445 and 0.7052 , respectively.

H2 (DV4)

As seen in Table 6, quite different variables explain most of the form of penetration from those which explain the first three variables. The profitability ratio (AVNIS) and the growth in sales per man (GRSPM) are consistently significant, the former at extremely high levels of significance and the latter at either 99 or 95 percent levels of significance. These two alone explain more than half the variance in the location ratio. Other variables which are occasionally significant are two ownership variables, average hourly compensation $(\mathrm{AHC})$ and relative sales per man (RSM). They are only significant in small groups, however, which suggests an overlap between many of these variables. Equation 4 of DV4 is a good example where differences in wage costs (RW) are significant at 99 percent, and RS at 95 percent, and where $R^{2}$ is 0.5633 . 


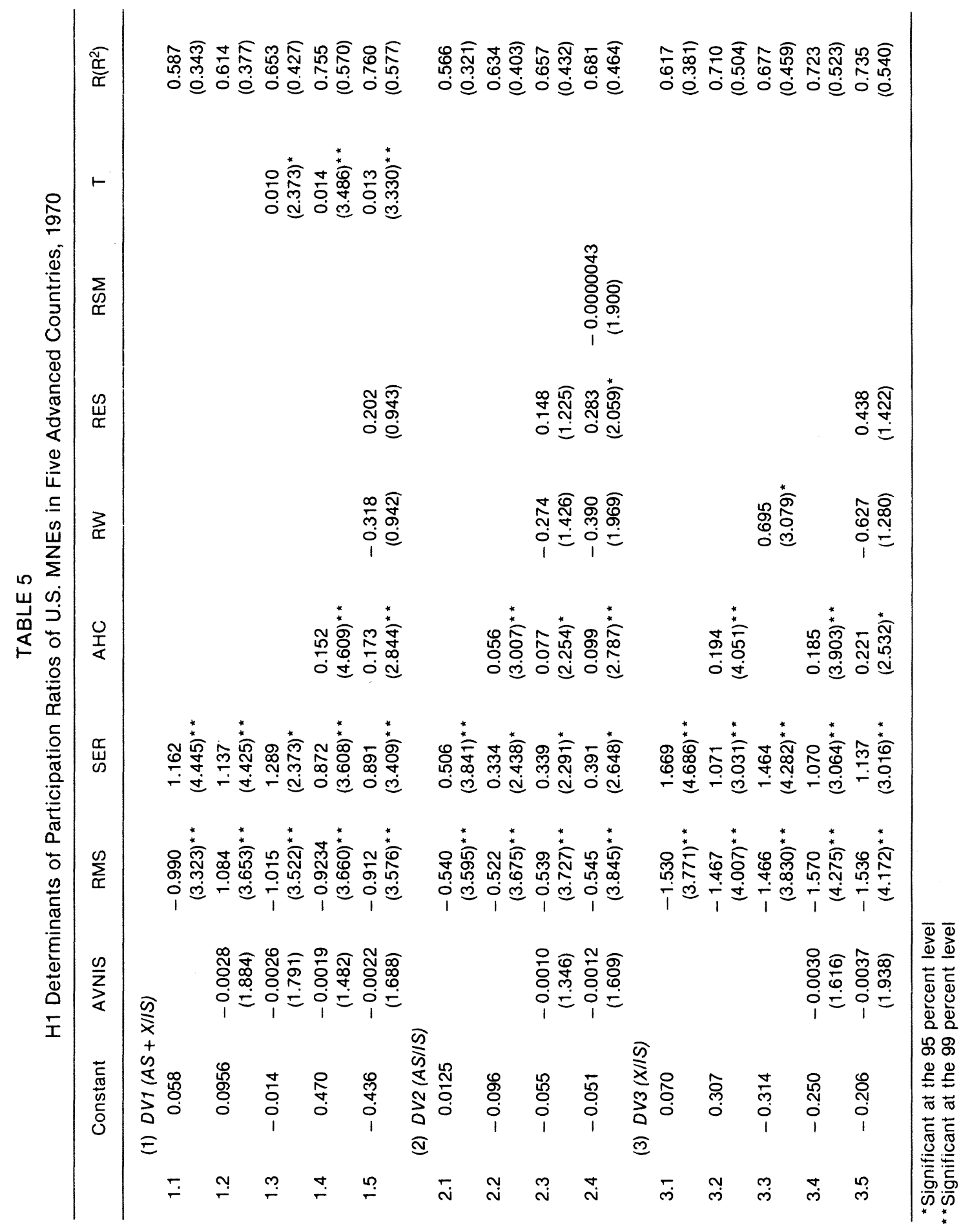




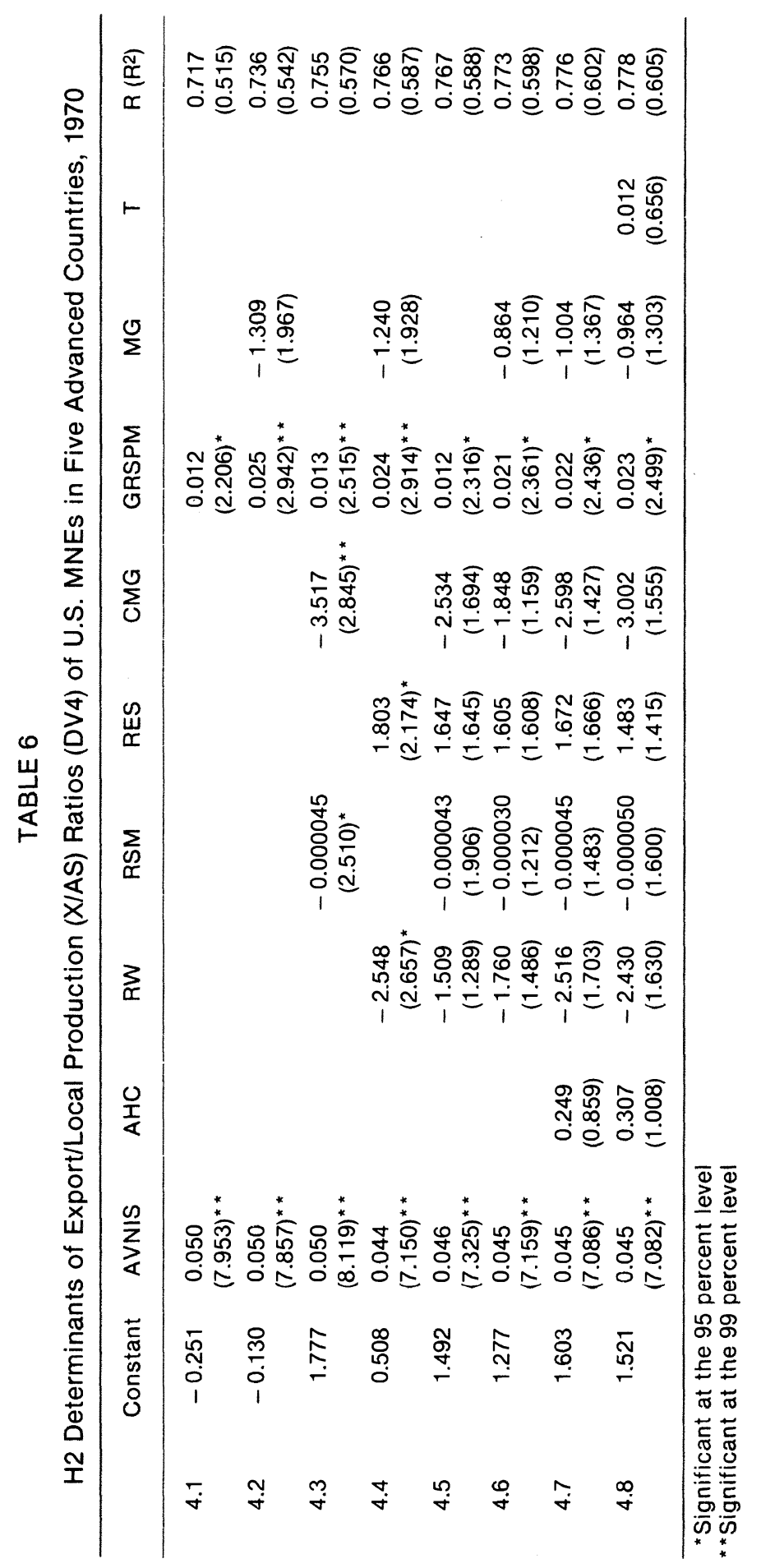


The data for 1966 yield similar results with country or industry (rather than ownership) differences in profitability (AVNIS) and growth in sales per man (GRSPM, an ownership variable) being rather more significant. But, in this case, MG (market share) becomes marginally significant in combination with GRSPM. None of the labor cost and productivity variables are significant.

Excluding Mexico and Brazil, the seven-country analysis produced some noticeable differences in the results of the statistical analysis. This section considers a few of these and speculates on the reasons for them.

First, the general level of the $R^{2}$ rises quite noticeably. This suggests that the independent variables used were more relevant in explaining export and affiliate success in the more advanced industrialized countries than in Mexico and Brazil. Running the regressions excluding Canada suggests that even higher $R^{2} s$ could have been obtained. (This run was not undertaken because it would have substantially reduced the degrees of freedom).

Second, the data for 1966 as well as for 1970 indicate that differences in wage costs (RW) and export shares (RS) tend to be more significant in explaining $\mathrm{H} 1$ (DV2) in the seven-country than in the five-country case. Perhaps these variables are too similar over different industries in the industrialized countries; and, not until the widely different figures for Mexico and Brazil are included, is their influence clearly indicated.

Third, AHC differences are significant in the compensation of the five-country but not in the seven-country case for H2 (DV4). This discrepancy is difficult to interpret. It may result from the less reliable figures on hourly compensation in Mexico and Brazil than in the other countries, or from the vastly different labor force structure which influences the extent to which local firms can compete successfully against imports in different ways.

Fourth, in the case of $\mathrm{H} 1$ (DV1), there are virtually no differences between Cases $A$ and $B$. There is one major difference between the two cases involving DV4: the export/import ratio (XMR) is significant with the larger group but not with the smaller. This may be interpreted to mean that the export potential of an industry may be more important in a less developed economy in determining the form of penetration. The negative sign implies that U.S. firms in those industries will tend to establish affiliates rather than export to the less developed countries, perhaps, to export some portion of their output. This is consistent in both the product cycle model's last stage and the growth of export-platform investments in some developing countries, including Mexico.

\section{CONCLUSION Comparing Case $A$ and Case B}


APPENDIX 1 The statistical analysis was restricted to common linear regression analysis and

Note on was carried out by Guy Landry at the University of Reading Computing Center. IniMethodology tially, single variable regressions with each of the independent variables and for each dependent variable were run. The purpose was to choose potentially useful explanatory variables from the number available. As a result of this a few variables were dropped because they either indicated no explanatory value or appeared less useful than very similar variables which were retained.

The next step involved multiple regressions. As explained in the body of the paper, the independent variables were divided into three categories:

a. The ownership-specific variables: SER, AHC, RSM, and GRSPM. These are variables suggested by industrial organization theory.

b. The country-specific variables: XMR, RMS, RW, RES, and CMG. These are mostly suggested by trade and location theory.

c. The general performance indicators: AVNIS and MG.

For each of the dependent variables, various combinations of the independent variables in each category were subjected to regression analysis. The most significant results are those shown in the tables. The purpose of this step was to determine which independent variables in each category best explained the dependent variables. Next, these same variables were analyzed, but with the categories grouped in different combinations. Once again the tables reveal the results. These particular equations should reveal the explanatory power of various combinations of the independent variables chosen from two or all three categories.

The values in brackets are the t-values: those marked by a single asterisk are significant at the 95 percent level, while those marked by two asterisks are significant at the 99 percent level.

The last column of each table gives the values of the coefficient of determination. 


\section{APPENDIX 2}

U.S. Affiliate Sales, U.S. Exports, and Total Industry Sales in Seven Countries, 1970

$$
\text { (Billion Dollars) }
$$

\begin{tabular}{|c|c|c|c|c|c|c|c|c|c|c|c|c|c|c|c|c|c|c|c|c|c|c|c|c|}
\hline & \multicolumn{3}{|c|}{ Canada } & \multicolumn{3}{|c|}{ United Kingdom } & \multicolumn{3}{|c|}{ France } & \multicolumn{3}{|c|}{ West Germany } & \multicolumn{3}{|c|}{ Belgium-Lux } & \multicolumn{3}{|c|}{ Mexico } & \multicolumn{3}{|c|}{ Brazil } & \multicolumn{3}{|c|}{ Total } \\
\hline & AS & $x$ & IS & AS & $x$ & IS & AS & $x$ & IS & AS & $x$ & IS & AS & $x$ & IS & AS & $x$ & IS & AS & $x$ & is & AS & $x$ & IS \\
\hline $\begin{array}{l}\text { Food Products } \\
\text { Paper and Allied }\end{array}$ & 2,220 & 98 & 8,532 & 1,054 & 56 & 10,294 & 473 & & 17,137 & 634 & 33 & 15,583 & 121 & 9 & 2,415 & 487 & 16 & 5,773 & 107 & 8 & 3,947 & 5,096 & 227 & 63,681 \\
\hline $\begin{array}{l}\text { Products } \\
\text { Chemicals and }\end{array}$ & 1,503 & 118 & 3,840 & 141 & 118 & 2,763 & 183 & 61 & 2,161 & 69 & 103 & 3,474 & 96 & 27 & 496 & 121 & 52 & 525 & 65 & 9 & 504 & 2,180 & 488 & 13,763 \\
\hline Allied Products & 2,124 & 554 & 2,490 & 1,918 & 226 & 9,356 & 971 & 107 & 8,190 & 963 & 215 & 13,888 & 654 & 220 & 1,357 & 764 & 171 & 3,888 & 6231 & 146 & 3,325 & 8,017 & 1,639 & 42,494 \\
\hline $\begin{array}{l}\text { Rubber Products } \\
\text { Primary and Fabri. }\end{array}$ & 613 & 146 & 628 & 373 & 22 & 1,185 & 119 & 24 & 1,854 & 211 & 36 & 1,972 & 79 & 13 & 96 & 108 & 19 & 267 & 175 & 9 & 363 & 1,678 & 269 & 6,365 \\
\hline cated Metals & 1,964 & 631 & 6,877 & 804 & 237 & 7,905 & 208 & 167 & 10,750 & 1,821 & 228 & 25,280 & 252 & 81 & 3,989 & 749 & 95 & 1,981 & 262 & 83 & 2,209 & 6,060 & 1,522 & 58,991 \\
\hline Nonelectric Mach. & 2,222 & 1,837 & 2,778 & 2,496 & 578 & 11,862 & 1,439 & 395 & 10,581 & 1,742 & 508 & 16,529 & 429 & 221 & 1,059 & 208 & 367 & 330 & 3042 & 247 & 895 & 8,840 & 4,153 & 44,034 \\
\hline Electrical Mach. & 1,822 & 603 & 2,213 & 1,607 & 221 & 8,961 & 514 & 136 & 6,059 & 876 & 237 & 13,888 & 425 & 52 & 993 & 478 & 195 & 919 & 246 & 49 & 1,014 & 5,968 & 1,493 & 34,047 \\
\hline Transp. Equipment & 5,600 & 2,430 & 6,222 & 3,430 & 211 & 12,645 & 936 & 180 & 12,086 & 3,250 & 261 & 12,843 & 275 & 139 & 1,523 & 567 & 239 & 1,2611 & 1,171 & 88 & 1,792 & 15,229 & 3,548 & 48,372 \\
\hline $\begin{array}{l}\text { Textiles \& Apparel } \\
\text { Lumber, Wood \& }\end{array}$ & 532 & 168 & 3,281 & 77 & 46 & 10,275 & 21 & 13 & 8,220 & 100 & 29 & 10,470 & 207 & 54 & 2,002 & 66 & 41 & 1,969 & 124 & 10 & 2,405 & 1,127 & 361 & 38,622 \\
\hline $\begin{array}{l}\text { Furniture } \\
\text { Printing \& }\end{array}$ & 1,322 & 91 & 2,632 & 35 & 22 & 2,763 & 15 & 4 & 3,135 & 33 & 25 & 4,475 & 0 & 2 & 478 & 5 & 16 & 316 & 5 & 1 & 705 & 1,415 & 161 & 14,504 \\
\hline Publishing & 176 & 153 & 1,516 & 125 & 29 & 5,003 & 51 & 4 & 4,320 & 35 & 6 & 2,589 & 5 & 2 & 390 & 6 & 9 & 396 & 4 & 4 & 429 & 401 & 207 & 14,643 \\
\hline Stone, Clay \& Glass & 406 & 140 & 1,260 & 242 & 14 & 3,818 & 252 & 13 & 2,897 & 239 & 20 & 6,043 & 45 & 7 & 727 & 191 & 19 & 725 & 76 & 5 & 821 & 1,451 & 218 & 16,291 \\
\hline Instruments & 563 & 219 & 626 & 739 & 101 & 1,321 & 399 & 48 & 1,976 & 406 & 90 & 1,608 & 15 & 21 & 33 & 76 & 42 & $\therefore$ & 91 & 26 & 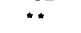 & 2,289 & 547 & 5,564 \\
\hline Other Manufacturing & 567 & 135 & 1,916 & 3,205 & 53 & 10,541 & 35 & 36 & 3,122 & 409 & 63 & 7,282 & 5 & 44 & 1,093 & 411 & 38 & 645 & 128 & 9 & 630 & 4,760 & 378 & 25,229 \\
\hline Total & 21,636 & 7,323 & 44,811 & 16,246 & 1,934 & 98,692 & 5,616 & 1,195 & 92,488 & 10,788 & 1,8541 & 135,9242 & 2,603 & 892 & 16,651 & 4,236 & 1,319 & 18,9953 & 3,3816 & 694 & 19,039 & 64,511 & 15,211 & 426,600 \\
\hline
\end{tabular}

" *missing 
APPENDIX 3

List of Industries (and Concordance)

\begin{tabular}{|c|c|c|c|c|c|c|}
\hline & & $\begin{array}{l}\text { BEA } \\
\text { Code }\end{array}$ & $\begin{array}{l}\text { SIC } \\
\text { Code }\end{array}$ & $\begin{array}{l}\text { SITC } \\
\text { Code }\end{array}$ & & \\
\hline 1. & Food Products & 410 & 20 & $\begin{array}{l}013 \\
023 \\
024 \\
032 \\
046\end{array}$ & $\begin{array}{l}047 \\
048 \\
053 \\
055 \\
061\end{array}$ & $\begin{array}{l}062 \\
092 \\
099 \\
111 \\
112\end{array}$ \\
\hline 2. & Paper and Allied Products & 420 & 26 & $\begin{array}{r}64 \\
251\end{array}$ & & \\
\hline 3. & Chemical and Allied Products & 430 & 28 & 5 & & \\
\hline 4. & Rubber & 440 & 30 & $\begin{array}{c}231.2 \\
62 \\
893\end{array}$ & & \\
\hline 5. & Primary and Fabricated Metals & 450 & 33 & $\begin{array}{c}67 \\
68 \\
69 \\
812.3\end{array}$ & & \\
\hline 6. & Nonelectrical Machinery & 460 & 35 & 71 & & \\
\hline 7. & Electrical Machinery & 470 & 36 & 72 & & \\
\hline 8. & Transportation Equipment & 480 & 37 & 73 & & \\
\hline 9. & Textiles and Apparel & 491 & $\begin{array}{l}22 \\
23\end{array}$ & $\begin{array}{r}65 \\
84 \\
266\end{array}$ & & \\
\hline 10. & Lumber, Wood and Furniture & 492 & $\begin{array}{l}24 \\
25\end{array}$ & $\begin{array}{r}63 \\
243 \\
82\end{array}$ & & \\
\hline 11. & Printing and Publishing & 493 & 27 & 892 & & \\
\hline 12. & Stone, Clay, and Glass Products & 495 & 32 & $\begin{array}{r}66 \\
-667\end{array}$ & & \\
\hline 13. & Instruments & 496 & 38 & $\begin{array}{r}86 \\
-863\end{array}$ & & \\
\hline 14. & $\begin{array}{l}\text { Ordnance, Leather, Tobacco, } \\
\text { and Other Manufacturing }\end{array}$ & $\begin{array}{l}494 \\
497 \\
498 \\
499\end{array}$ & $\begin{array}{l}19 \\
21 \\
31 \\
39\end{array}$ & $\begin{array}{r}122 \\
61 \\
667 \\
81 \\
-812.3 \\
83 \\
85\end{array}$ & $\begin{array}{l}891 \\
894 \\
895 \\
897 \\
899 \\
951.0\end{array}$ & \\
\hline
\end{tabular}

FOOTNOTES 1. Throughout this article, assets and endowments are used interchangeably, and in the Fisherian sense, to mean "anything capable of generating a future income stream" [Johnson 1970].

2. See John H. Dunning, "Trade, Location of Economic Activity and the Multinational Enterprise," pp. 395-418.

3. In this article, distance from foreign markets is treated as a negative location-specific endowment.

4. Moreover, since perfect competition and identical production functions between firms were two of the assumptions underlying the theories, they were not interested in explaining the international activities of firms-only of countries. 
5. For example, unused overheads of the parent company may be supplied to a branch plant at a much lower marginal cost than the average cost of supplying them by a de novo firm.

6. For further details and also those which especially arise from producing in a foreign location see Dunning [1977] and the references at the end of the Chapter. The most comprehensive theoretical treatment of the internalizing theory of international production is contained in Buckley and Casson [1976].

7. Among these one might mention particularly those of Horst [1972 (a) and (b), 1975]. (In this latter paper the author explicitly acknowledges the importance of internalizing advantages). The study of Wolf [1973] is also particularly pertinent to explain why firms choose to engage in foreign direct investment, rather than other forms of growth. Research on host country data includes: Baumann [1975]; Caves [1974]; Buckley and Dunning [1976]; and Owen [1979].

8. See particularly the studies of Hirsch [1976], Buckley and Pearce [1979], Hawkins and Webbink [1976], Parry [1976]. The question of the extent to which trade and foreign investment substitute for each other has been very well explored by Lipsey and Weiss [1973; 1976], Cornell [1973], and Horst [1974].

9. There has been only limited empirical testing of this approach. The Hirsch contribution [1976] is again very relevant. See also Buckley and Dunning [1977].

10. Here the work of Buckley and Casson [1976] is especially relevant.

11. A summary of each of these approaches is contained in an earlier version of this paper:

"Trade, Location of Economic Activity and the Multinational Enterprise: Some Empirical Evidence." University of Reading Discussion Papers in International Investment and Business Studies No. 37, October 1977.

12. The complications of this assumption will be dealt with later in the paper. See also Horst, 1974.

13. For a more detailed analysis of these data, see Dunning paper quoted in footnote 11. 14. Extracted is the possibility that firms might supply foreign markets from third locations.

15. Consumption figures would have been more appropriate but these figures were not available.

16. For some purposes, we may wish to normalize the ratio $A S+X / I S$ in a particular industry (i), $A S_{i}+X_{i} / I S_{i}$, by dividing the ratio by that for all industry (t), $A S_{i}+X_{t} / I S_{t}$. The result is an index of the comparative rather than the absolute competitive advantage of U.S. firms. This allows cross-country comparisons to be made.

17. But see Dunning and Buckley, 1976.

18. I.e., that some ownership advantages are not independent of the location or production. See also Dunning, 1979.

19. For a different approach to the measurement of these advantages see Buckley and Casson, 1976.

20. See footnote 8 .

Brown, W. E. "Island of Consensus Power: MNCs in the Theory of the Firm MSU." Business Topics, Summer 1976.

Baumann, H. G. "Merger Theory, Property Rights and the Pattern of U.S. Direct Investment in Canada." Weltwirtschaftliches Archiv III Heft 4, 1975.

Buckley, P. J., and Casson, M. C. The Future of the Multinational Enterprise. London: MacMillan, 1976.

Buckley, P. J., and Dunning, J.H. "The Industrial Structure of U.S. Direct Investment in the U.K." Journal of International Business Studies, Summer 1976.

Buckley, P. J., and Pearce, R. D. "Overseas Production and Exporting by the World's Largest Enterprises." Journal of International Business Studies, Spring/Summer 1979.

Caves, R. E. "International Corporations: The Industrial Economics of Foreign Investment." Economica, February 1971.

Caves. R. E. "The Causes of Direct Investment: Foreign Firms' Shares in Canadian and UK Manufacturing Industries." Review of Economics and Statistics, August 1974.

Cornell, R. "Trade of Multinational Firms and Nation's Comparative Advantage." Paper presented to a Conference on Multinational Corporations and Governments, UCLA, November 1973.

Dunning, J. H. "The Determinants of International Production." Oxford Economic Papers, November 1973. 
Dunning, J. H. "Trade Location of Economic Activity and the Multinational Enterprise. A Search for an Eclectic Approach" in The International Allocation of Economic Activity, edited by B. Ohlin, P. O. Hesselborn, and P. J. Wiskman, London: MacMillan, 1977.

Dunning, J. H., and Buckley, P. J. International Production and Alternative Models of Trade. Manchester School of Economic and Social Studies 45, December 1977.

Dunning, J. H. "Explaining Changing Patterns of International Production: in Defense of the Eclectic Theory." Oxford Bulletin of Economics and Statistics, November 1979.

Hawkins, R., and Webbink, E. S. "Theories of Direct Foreign Investment: A Survey of Em. pirical Evidence." Unpublished Manuscript.

Hirsch, S. "Capital or Technology? Confronting the Neo-Factor Proportions and NeoTechnology Accounts of International Trade." Weltwirtschaftliches Archiv 114 Heft. 2. 1974.

Hirsch, S. "An International Trade and Investment Theory of the Firm." Oxford Economic Papers, July 1976.

Horst, T. "Firm and Industry Determinants of the Decision to Invest Abroad: An Empirical Study." Review of Economics and Statistics, August 1972 (a).

Horst, T. "The Industrial Composition of U.S. Exports and Subsidiary Sales to the Canadian Market." American Economic Review, March 1972 (b).

Horst, T. American Exports and Foreign Direct Investments. Harvard Institute of Economic Research Discussion 362, May 1974.

Horst, T. "American Investments Abroad: and Domestic Market Power." Brookings Institution: Unpublished, 1975.

Hufbauer, G. C. "The Impact of National Characteristics and Technology on the Commodity Composition of Trade in Manufactured Goods," in The Technology Factor in International Trade, edited by R. Vernon. New York: Columbia University Press, 1970.

Hufbauer, G. C., and Adler, M. Overseas Manufacturing Investment and the Balance of Payments. U.S. Treasury Department, 1968.

Johnson, $H$. "The Efficiency and Welfare Implications of the International Corporation," in The International Corporation, edited by C. P. Kindleberger. Cambridge: M.I.T. Press, 1970. Knickerbocker, F. T. Oligopolistic Reaction and the Multinational Enterprise. Cambridge, MA: Harvard University Press, 1973.

Kojima, K. "A Macro-Economic Approach to Foreign Direct Investment." Hitotsubashi Journal of Economics, June 1973.

Lipsey, P. E., and Weiss, M. Y. "Multinational Firms and the Factor Intensity of Trade." National Bureau of Economic Research, Working Paper No. 8, 1973.

Lipsey, R. E., and Weiss, M. Y. "Exports and Foreign Investment in the Pharmaceutical Industry." National Bureau of Economic Research, Working Paper No. 87 (Revised), 1976 (a). Lipsey, R. E., and Weiss, M. Y. "Exports and Foreign Investment in Manufacturing Industries." National Bureau of Economic Research. Working Paper No. 13 (Revised), 1976 (b).

Nurkse, R. "The Problems of International Investment Today in the Light of 19th Century Experience." Economic Journal, December 1954.

Owen, R. F. Interindustry Determinants of Foreign Direct Investments: A Perspective Emphasizing the Canadian Experience. Working Paper in International Economics (G-79-03), Princeton University, 1979.

Parry, T. C. "Trade and Non Trade Performance of US Manufacturing Industry: 'Revealed' Comparative Advantage." Manchester School of Economics and Social Studies, June 1973. Parry, T. C. Methods of Servicing Overseas Markets: The UK Owned Pharmaceutical Study. University of Reading Discussion Paper (Series 2) 27, 1976.

Political and Economic Planning "Atlantic Tariffs and Trade." A Report by PEP. Winchester, MA: Allen and Unwin, 1967.

Rugman, A. International Diversification and the Multinational Enterprise. Lexington, MA: Lexington Books, 1979.

Stevens, C. V. "Determinants of Investment," in Economic Analysis and the Multinational Enterprise, edited by J. H. Dunning: Winchester, MA: Allen and Unwin, 1974.

Swedenborg, B. The Multinational Operations of Swedish Firms: An Analysis of Determinants and Effects. Stockholm: Almquist \& Wiksell International, 1979.

U.S. Tariff Commission. Implications of Multinational Firms for World Trade and Investment and for US Trade and Labor. Washington, DC: Government Printing Office, 1973.

Vaupel, J. Characteristics and Motivations of the US Corporations which Invest Abroad. Unpublished ms.

Vernon, R. "International Investment and International Trade in the Product Cycle." Quarterly Journal of Economics, May 1966. 
Vernon, R. "The Location of Economic Activity," in Economic Analysis and the Multinational Enterprise, edited by J. H. Dunning. Winchester, MA: Allen and Unwin, 1974.

Wolf, B. "Industrial Diversification and Internationalization: Some Empirical Evidence. Journal of Industrial Economics, December 1977. 